\title{
Co-Formulations as the First Injectable in Type 2 Diabetes: A Review of Efficacy, Safety, and Implications in Clinical Practice
}

\author{
Mathew John Deepa Gopinath Tittu Oommen \\ Providence Endocrine and Diabetes Specialty Centre, Trivandrum, India
}

\author{
Keywords \\ Co-formulations · Diabetes mellitus · IDegAsp · IDegLira · \\ IGlarLixi
}

\begin{abstract}
Background: Progression of type 2 diabetes will necessitate the use of injectable therapies in a significant number of people. Co-formulations of degludec with liraglutide (IDegLira) and glargine with lixisenatide (IGlarLixi) are currently recommended for intensification in people with type 2 diabetes on basal insulin or glucagon-like peptide receptor agonist (GLP-1RA) alone or in people with type 2 diabetes who are naïve to insulin with very high glycated haemoglobin. Co-formulation of aspart with degludec (IDegAsp) is recommended as a substitute for premixed insulin. The aim of this article is to review the evidence in the use of co-formulations as the first injectable in type 2 diabetes and its clinical implications. Summary: In people with type 2 diabetes who are naïve to insulin or GLP-1RA, IDegLira and IGlarLixi achieved stable and durable glycaemic control over a wide range of baseline glycated haemoglobin (HbA1c) levels. People on IDegLira and IGlarLixi had lesser risk of hypoglycaemia and weight gain in studies compared to basal insulin and lesser
\end{abstract}

gastrointestinal adverse effects in comparison to GLP-1RA. IDegAsp achieved similar glycaemic control to basal and premixed insulin with lesser risk of nocturnal hypoglycaemia. Key Messages: IDegLira, IGlarLixi, and IDegAsp can be used as the first injectable in people with type 2 diabetes with very high glycated haemoglobin on oral antidiabetic drugs. These co-formulations combine efficacy and durability with lesser injection burden. The components of these agents have proven cardiovascular and renal safety. Their limitations in flexibility of dosing, renal and cardiovascular considerations, and adverse effects are discussed.

(c) 2020 The Author(s)
Published by S. Karger AG, Basel

\section{Introduction}

Type 2 diabetes is a major public health problem worldwide with the disease and its complications leading to high healthcare costs [1]. Glycaemic control along with the control of blood pressure and lipids form the cornerstone in preventing microvascular and macrovascular complications. As the duration of diabetes increases, more people require the use of injectable therapies for optimisation of their glycaemic control. Although insulin karger@karger.com www.karger.com/dde

Karger ${ }^{\prime \prime}=$

BOPEN ACCESS
(C) 2020 The Author(s)

Published by S. Karger AG, Basel

This article is licensed under the Creative Commons AttributionNonCommercial-NoDerivatives 4.0 International License (CC BY NC-ND) (http://www.karger.com/Services/OpenAccessLicense) Usage and distribution for commercial purposes as well as any distribution of modified material requires written permission.
Mathew John, MD, DM(Endo)

Department of Endocrinology and Diabetes Providence Endocrine and Diabetes Specialty Centre SMRA 104, Ulloor, Trivandrum 695011 (India) drmathewjohn@yahoo.com 
is the traditional injectable, new guidelines recommend glucagon-like peptide receptor agonist (GLP-1RA) as the preferred injectable in people with type 2 diabetes [2-4]. For people who require further optimisation of glycaemic control, insulin is preferred although a significant number of people would be initiated on insulin directly [2]. However, co-formulations of insulin and fixed ratio combinations of GLP-1RA and basal insulin are newer options which are increasingly used in clinical practice. This review focuses on the use of these novel agents as the first injectable for people with type 2 diabetes.

\section{Position of GLP-1RA, Basal Insulin Analogues, and Co-Formulations in the Current Guidelines}

The early introduction of insulin should be considered if there is evidence of ongoing catabolism, if symptoms of hyperglycaemia are present, or when A1C levels ( $>10 \%$ [86 $\mathrm{mmol} / \mathrm{mol}])$ or blood glucose levels $(\geq 300 \mathrm{mg} / \mathrm{dL}[16.7$ $\mathrm{mmol} / \mathrm{L}])$ are very high. In appropriate high-risk individuals with established type 2 diabetes, the decision to treat with a GLP-1 receptor agonist or SGLT2 inhibitor to reduce major adverse cardiovascular events, hospitalisation for heart failure, cardiovascular death, or chronic kidney disease progression should be considered independently of baseline $\mathrm{HbAlc}$ or individualized $\mathrm{HbA} 1 \mathrm{c}$ target. In others, the choice of the second agent after metformin is less empiric and is driven by consideration of adverse effects: hypoglycaemia, weight gain, renal function, and so on [2-5].

Due to the progressive nature of the disease, most people with type 2 diabetes will need injectable agents as they offer better glycaemic reduction than most oral agents. GLP-1RAs have consistently shown better glycaemic efficacy, lower risk of hypoglycaemia and weight loss in comparison to basal insulin in people with type 2 diabetes [6-9]. This makes them the choice as first injectable for most people with type 2 diabetes. Basal insulin is added to GLP-1RA if glycaemic targets are not met $[2,3]$.

Most guidelines recommend basal insulin as the first insulin preparation and advancing to prandial or premixed insulin for intensification [2-5]. The advantages of a single injection, a flat pharmaco-kinetic profile, easy titration, and less incidence of hypoglycaemia in comparison to premixed insulins, make basal insulins an ideal choice for initiation [10]. In trials comparing different insulins for initiation, premixed analogues resulted in a higher reduction in $\mathrm{HbAlc}$ and more people reaching the goal. However, the overall risk of hypoglycaemia and weight gain was also more with premixed insulin $[10,11]$.
Adding and titrating a basal insulin or GLP-1RA alone to oral agents have various limitations. Basal insulin targets the fasting hyperglycaemia by supressing hepatic glucose output. Treat-to-target regimens continue to up-titrate basal insulin based on fasting plasma glucose (FPG) to reach target levels of 3.9-5.0 mmol/L [12]. However, in these studies, the achieved levels of FPG are higher than the target values, probably limited by the increased risk of nocturnal hypoglycaemia, and a significant percentage of people do not reach the HbA1c goals $[12,13]$. In a metaanalysis of 48 basal insulin analogue trials, only $41 \%$ of the study participants attained an HbAlc of $<53 \mathrm{mmol} /$ mol (7.0\%) [14]. Despite optimum titration in trials, basal insulin has less durability and limited benefits on postprandial glucose (PPG) $[15,16]$. With increasing doses, basal insulin has a diminishing impact on glycaemic control with weight gain [17]. Similarly, adding a GLP-1RA alone to oral agents has limitations in terms of gastrointestinal adverse effects and less people reaching the $\mathrm{HbAlc}$ goals. In studies where the highest approved doses of semaglutide, liraglutide, dulaglutide, and exenatide QW were added on to oral glucose-lowering agents in people with type 2 diabetes, the percentages of people achieving $\mathrm{HbAlc}<53 \mathrm{mmol} / \mathrm{mol}(7.0 \%)$ were $73,53,53$, and $40 \%$, respectively [6-9]. Intensification of people started on one injectable (basal insulin or GLP-1RA) is done with the other injectable for further lowering of HbAlc.

As per recent guidelines, degludec with liraglutide (IDegLira) and glargine with lixisenatide (IGlarLixi) are recommended as a replacement for people on GLP-1RA or basal insulin if they fail to reach targets [2]. Aspart with degludec (IDegAsp), the first insulin co-formulation, is considered as a substitute for premixed analogues with lesser risk of nocturnal hypoglycaemia [18-20].

\section{Types of Co-Formulations}

Injectable co-formulations are preparations where 2 distinct drugs are combined, with each maintaining their distinct pharmaco-dynamic and pharmaco-kinetic properties [21]. The co-formulations currently available include insulin-based co-formulation, IDegAsp and GLP1RA-basal insulin fixed ratio combinations, IDegLira, and IGlarLixi (Table 1).

\section{IDegAsp}

IDegAsp is a co-formulation of short-acting insulin analogue aspart with long-acting basal insulin degludec in a fixed dose of 30:70 proportion $(100 \mathrm{U} / \mathrm{mL})$. The unique pharmaco-kinetic and pharmaco-dynamic pro- 
Table 1. Overview of co-formulations

\begin{tabular}{|c|c|c|c|c|c|c|}
\hline $\begin{array}{l}\text { Co- } \\
\text { formulation }\end{array}$ & $\begin{array}{l}\text { Components and } \\
\text { proportion }\end{array}$ & Dosing & $\begin{array}{l}\text { Maximum dose of individual } \\
\text { components delivered in a } \\
\text { single injection }\end{array}$ & $\begin{array}{l}\text { Delivery per } \\
\text { dosing change }\end{array}$ & $\begin{array}{l}\text { Cartridge } \\
\text { volume }\end{array}$ & $\begin{array}{l}\text { Year of } \\
\text { approval } \\
\text { (FDA/EMA) }\end{array}$ \\
\hline IDegAsp & $\begin{array}{l}70 \% \text { ultra-long- } \\
\text { acting insulin } \\
\text { degludec (IDeg) } \\
\text { and } 30 \% \text { rapid- } \\
\text { acting insulin } \\
\text { aspart (IAsp) }\end{array}$ & $\begin{array}{l}\text { Starting dose in insulin-naïve people } \\
\text { with type } 2 \text { diabetes mellitus is } 10 \text { units } \\
\text { once daily along with the largest meal } \\
\text { It can also be used twice daily }\end{array}$ & $\begin{array}{l}\text { The disposable pen/cartridge } \\
\text { can deliver } 80 \text { units } \\
\text { The permanent device can } \\
\text { deliver } 60 \text { units }\end{array}$ & $\begin{array}{l}0.7 \text { unit degludec } \\
\text { and } 0.3 \text { unit } \\
\text { aspart in } 1 \text { unit } \\
\text { IDegAsp } \\
\text { It is dosed as } \\
\text { units }\end{array}$ & $3 \mathrm{~mL}$ & $2015 / 2013$ \\
\hline IDegLira & $\begin{array}{l}100 \mathrm{U} / \mathrm{mL} \\
\text { degludec and } 3.6 \\
\mathrm{mg} / \mathrm{mL} \text { liraglutide }\end{array}$ & $\begin{array}{l}\text { Starting dose is } 10 \text { dose steps in } \\
\text { insulin-naïve people ( } 10 \text { units of } \\
\text { insulin degludec and } 0.36 \mathrm{mg} \\
\text { liraglutide) administered at any time of } \\
\text { the day, preferably at the same time of } \\
\text { the day } \\
\text { When transferring from basal insulin } \\
\text { therapy, the recommended starting } \\
\text { dose of IDegLira is } 16 \text { dose steps ( } 16 \\
\text { units insulin degludec and } 0.58 \mathrm{mg} \\
\text { liraglutide) }\end{array}$ & $\begin{array}{l}50 \text { units of degludec and } 1.8 \\
\text { mg of liraglutide }\end{array}$ & $\begin{array}{l}1 \text { unit of insulin } \\
\text { degludec and } \\
0.036 \mathrm{mg} \\
\text { liraglutide in } 1 \\
\text { dose step of } \\
\text { IDegLira }\end{array}$ & $3 \mathrm{~mL}$ & $2016 / 2014$ \\
\hline IGlarLixi & $\begin{array}{l}\text { Glargine }(100 \mathrm{U} / \\
\mathrm{mL}) \text { and } \\
\text { lixisenatide }(33 \\
\mu \mathrm{g} / \mathrm{mL})\end{array}$ & $\begin{array}{l}\text { It is available in a } 3: 1 \text { dosing ratio of } \\
3 \text { units insulin glargine to } 1 \mu \mathrm{g} \\
\text { lixisenatide per } \mathrm{mL} \\
\text { Starting dose is } 15 \text { units glargine } / 5 \mu \mathrm{g} \\
\text { lixisenatide ( } 15 \text { units dlargine in dial) } \\
\text { for people on lixisenatide or }<30 \text { units } \\
\text { glargine } \\
\text { The starting dose is } 30 \text { units glargine } \\
\text { and } 10 \mu \text { g lixisenatide for people on } \\
>30 \text { units glargine } \\
\text { Administered once daily within } 1 \text { hour } \\
\text { before the first meal of the day }\end{array}$ & $\begin{array}{l}60 \text { units glargine and } 20 \mu g \\
\text { lixisenatide }\end{array}$ & $\begin{array}{l}1 \text { dose step } \\
\text { delivers } 1 \text { unit } \\
\text { of glargine and } \\
0.3-0.4 \mu g \text { of } \\
\text { lixisenatide }\end{array}$ & $3 \mathrm{~mL}$ & $2016 / 2017$ \\
\hline
\end{tabular}

file help it in using it either once daily or twice daily according to the glycaemic fluctuations [20] (Table 1).

\section{IDegLira}

IDegLira is a fixed-ratio combination of insulin degludec and liraglutide, containing $100 \mathrm{U} / \mathrm{mL}$ of IDeg and $3.6 \mathrm{mg} / \mathrm{mL}$ of liraglutide. Liraglutide is a long-acting GLP-1RA which reduces both FPG and PPG excursions via its glucose-dependent effects on $\beta$ - and $\alpha$-cell function. The dose should be titrated according to the mean of 3 or 4 consecutive pre-breakfast self-measured plasma glucose results, and according to the individual's glycaemic target range [22-24] (Table 1).

\section{IGlarLixi}

IGlarLixi contains insulin glargine U100 (IGlarU100), a long-acting basal insulin analogue, and lixisenatide, a short-acting GLP-1RA. It is currently approved for improving glycaemic control in adults with type 2 diabetes inadequately controlled on basal insulin ( $<60 \mathrm{U}$ daily) or lixisenatide [25]. As IGlarLixi is currently approved only for individuals with type 2 diabetes on basal insulin or lixisenatide, the starting dose is also decided based on the current dose $[23,25,26]$ (Table 1).

\section{Search Strategy}

We searched PubMed through November 2019 for trials involving IDegAsp, IDegLira, and IGlarLixi. Eligible studies were randomised controlled trials of IDegAsp, IDegLira, or IGlarLixi compared with placebo or active comparators (GLP-1RA, insulin, or oral glucose-lowering drugs) in people with type 2 diabetes mellitus who were naïve to injectable therapies (see online suppl. File 1, www.karger.com/doi/10.1159/000509045). 
Table 2. Efficacy of IDegAsp in studies where it was used as a first injectable therapy

\begin{tabular}{|c|c|c|c|c|c|c|c|}
\hline Reference & Comparator & $\begin{array}{l}\text { Duration } \\
\text { of trial }\end{array}$ & $\begin{array}{l}\text { Mean change in HbAlc } \\
\text { (vs. comparator) }\end{array}$ & $\begin{array}{l}\text { Estimated treatment } \\
\text { difference in } \mathrm{HbAlc}\end{array}$ & $\begin{array}{l}\text { Percentage of patients } \\
\text { reaching target HbA1c } \\
\text { (vs. comparator) }\end{array}$ & $\begin{array}{l}\text { Percentage of } \\
\text { patients reaching } \\
\text { target HbAlc } \\
\text { without hypogly- } \\
\text { caemia } \\
\text { (vs. comparator) }\end{array}$ & $\begin{array}{l}\text { Estimated treatment } \\
\text { difference in fasting } \\
\text { blood glucose }\end{array}$ \\
\hline $\begin{array}{l}\text { Kumar } \\
\text { et al. [27] }\end{array}$ & IGlarU100 & $\begin{array}{l}26 \text { weeks' } \\
\text { core phase } \\
\text { and } \\
\text { extension } \\
\text { phase to } \\
52 \text { weeks }\end{array}$ & $\begin{array}{l}-17 \mathrm{mmol} / \mathrm{mol}(1.65 \%) \\
\text { at } 26 \text { weeks and }-15 \\
\mathrm{mmol} / \mathrm{mol}(1.39 \%) \text { at } \\
52 \mathrm{weeks}(-19 \mathrm{mmol} / \\
\mathrm{mol}[1.72 \%] \text { at } 26 \text { weeks } \\
\text { and }-14 \mathrm{mmol} / \mathrm{mol} \\
[1.34 \%] \text { at } 52 \text { weeks })\end{array}$ & $\begin{array}{l}0.03 \%(95 \% \text { CI } \\
-0.14 \text { to } 0.20) \text { at } \\
26 \text { weeks } \\
0.08 \%(95 \% \text { CI } \\
-0.26 \text { to } 0.09) \text { at } \\
52 \text { weeks }\end{array}$ & $\begin{array}{l}45.9 \% \text { at } 26 \text { weeks, } \\
33.1 \% \text { at } 52 \text { weeks } \\
\text { (vs. } 45.6 \% \text { at } 26 \\
\text { weeks, } 29.7 \% \text { at } 52 \\
\text { weeks) }\end{array}$ & NA & $\begin{array}{l}0.51 \mathrm{mmol} / \mathrm{L}(95 \% \\
\mathrm{CI} 0.09 \text { to } 0.93) \text { at } \\
\text { week } 26 \text { and } 0.28 \\
\mathrm{mmol} / \mathrm{L}(95 \% \mathrm{CI} \\
-0.14 \text { to } 0.69) \text { at } \\
\text { week } 52\end{array}$ \\
\hline $\begin{array}{l}\text { Onishi } \\
\text { et al. [28] }\end{array}$ & IGlarU100 & 26 weeks & $\begin{array}{l}-15 \mathrm{mmol} / \mathrm{mol}(1.4 \% \text {; } \\
\text { vs. }-13 \mathrm{mmol} / \mathrm{mol} \\
[1.2 \%])\end{array}$ & $\begin{array}{l}-0.28 \%(95 \% \mathrm{CI} \\
-0.46 \text { to }-0.10)\end{array}$ & $\begin{array}{l}59 \%(\text { vs. } 40 \%) \\
(p \text { value }<0.01)\end{array}$ & $\begin{array}{l}43 \%(\text { vs. } 25 \%) \\
(p \text { value }<0.01)\end{array}$ & $\begin{array}{l}0.15 \mathrm{mmol} / \mathrm{L}(95 \% \\
\mathrm{CI},-0.29 \text { to } 0.60) \\
p=\text { not significant }\end{array}$ \\
\hline $\begin{array}{l}\text { Shimoda } \\
\text { et al. [29] }\end{array}$ & $\begin{array}{l}\text { Basal insulin } \\
\text { (IDeg or } \\
\text { IGlarU300) }\end{array}$ & 12 weeks & $\begin{array}{l}-14 \mathrm{mmol} / \mathrm{mol}(1.29 \% \text {; } \\
\text { vs. }-18 \mathrm{mmol} / \mathrm{mol} \\
[1.6 \%])^{\#}\end{array}$ & $0.31 \% \#$ & $\begin{array}{l}57.7 \%^{\# \#}\left(\text { vs. } 69.2 \%^{\# \#}\right) \\
(p \text { value } 0.388)\end{array}$ & NA & NA \\
\hline $\begin{array}{l}\text { Franek } \\
\text { et al. [30] }\end{array}$ & BIAsp30 & 26 weeks & $\begin{array}{l}-19 \mathrm{mmol} / \mathrm{mol}(1.71 \% \\
\mathrm{vs}-19.2 \mathrm{mmol}[1.73 \%])\end{array}$ & $\begin{array}{l}0.02 \%(95 \% \mathrm{CI} \\
-0.12 \text { to } 0.17)\end{array}$ & NA & NA & $\begin{array}{l}-1.0 \mathrm{mmol} / \mathrm{l}(95 \% \\
\mathrm{CI}-1.4 \text { to }-0.6) \\
p<0.001\end{array}$ \\
\hline $\begin{array}{l}\text { Park } \\
\text { et al. [31] }\end{array}$ & $\begin{array}{l}\text { Comparison of } \\
\text { two self-titration } \\
\text { algorithms of } \\
\text { IDegAsp OD } \\
\text { (IDegAsp simple vs. } \\
\text { IDegAsp } \\
\text { stepwise) }\end{array}$ & 26 weeks & $\begin{array}{l}-15 \mathrm{mmol} / \mathrm{mol}\left(1.4 \%^{*}\right) \\
\text { and }-11 \mathrm{mmol} / \mathrm{mol} \\
\left(1.0 \%^{* *}\right)\end{array}$ & $\begin{array}{l}-0.2 \%(95 \% \mathrm{CI} \\
-0.4 \text { to } 0.02)\end{array}$ & $58.1 \% *, 49.3 \% * *$ & $39.5 \% *, 30.7 \% * *$ & $\begin{array}{l}-0.4 \mathrm{mmol} / \mathrm{l}(95 \% \\
\mathrm{CI}-0.9 \text { to } 0.09)\end{array}$ \\
\hline
\end{tabular}

* Twice weekly titration, based on a single pre-breakfast self-monitored plasma glucose (SMPG) measurement. ** Weekly titration, based on the lowest of three consecutive pre-breakfast SMPG measurements. ${ }^{\#}$ Indirectly derived from the parameters used in the study. \# The target HbA1c was $<8 \%$ in Shimoda et al.'s study [29], in the rest, it was $<7 \%$. NA, not reported in the text or supplementary appendix.

\section{Glycaemic and Metabolic Outcomes with Co-Formulations}

\section{Evidence with IDegAsp (Tables 2, 3)}

In an open-label, parallel-group, treat-to-target trial, people with type 2 diabetes who were naïve to insulin $(n=$ 530, BMI: 30.9, mean age: 57.4 years, duration of diabetes: 8.7 years) were randomised (1:1) to receive IDegAsp OD (breakfast, $n=266$ ) or IGlarU100 OD (as per label, $n=264$ ) lasting 26 weeks. Participants then entered a 26-week extension phase (IDegAsp OD, $n=192$; IGlarU100 OD, $n=$ 221). IDegAsp was non-inferior to IGlarU100 for the primary endpoint of difference of $\mathrm{HbAlc}$ from the baseline at 52 weeks. The percentage of people reaching target $\mathrm{HbAlc}$ was also similar in both groups at 26 and 52 weeks [27].

In a phase 3 treat-to-target study in Japanese people with type 2 diabetes who were naïve to insulin $(n=296$, 26-week duration, mean BMI: 25, duration of diabetes: 10.9 years, mean age: 60 years), the efficacy and safety of IDegAsp before the main meal was compared to IGlar-
U100 as an initiation strategy. The study showed superiority of IDegAsp in reducing $\mathrm{HbAlc}$ from baseline with a clinically relevant treatment difference of $0.28 \%$ in favour of IDegAsp. More people in the IDegAsp arm (59\%) reached an $\mathrm{HbAlc}$ of $<53 \mathrm{mmol} / \mathrm{mol}(7.0 \%)$ and more people $(43 \%)$ reached $\mathrm{HbAlc}<53 \mathrm{mmol} / \mathrm{mol}(7.0 \%)$ without hypoglycaemia $(p<0.01)$ [28].

In a small trial $(n=52)$ in Japanese people, IDegAsp was compared to basal insulins IGlarU300 and IDeg. The reduction in $\mathrm{HbA} 1 \mathrm{c}$ and proportion of people reaching a target $\mathrm{HbAlc}$ of $64 \mathrm{mmol} / \mathrm{mol}(8 \%)$ were similar. In a subgroup analysis of people stratified by baseline $\mathrm{HbAlc}$, IDegAsp fared better than basal insulins in people with baseline $\mathrm{HbAlc}<69 \mathrm{mmol} / \mathrm{mol}(8.5 \%)$, whereas basal insulins fared better in people with $\mathrm{HbA} 1 \mathrm{c}>69 \mathrm{mmol} / \mathrm{mol}$ $(8.5 \%)$. These conclusions were limited by the small number of people enrolled and the less stringent targets for FPG and HbA1c [29].

In a trial lasting 26 weeks (BMI: 31.2, duration of diabetes: 9.5 years, baseline HbA1c: $68 \mathrm{mmol} / \mathrm{mol}$ [8.4\%]), 
Table 3. Safety, doses, and weight changes in trials of IDegAsp when used as the first injectable

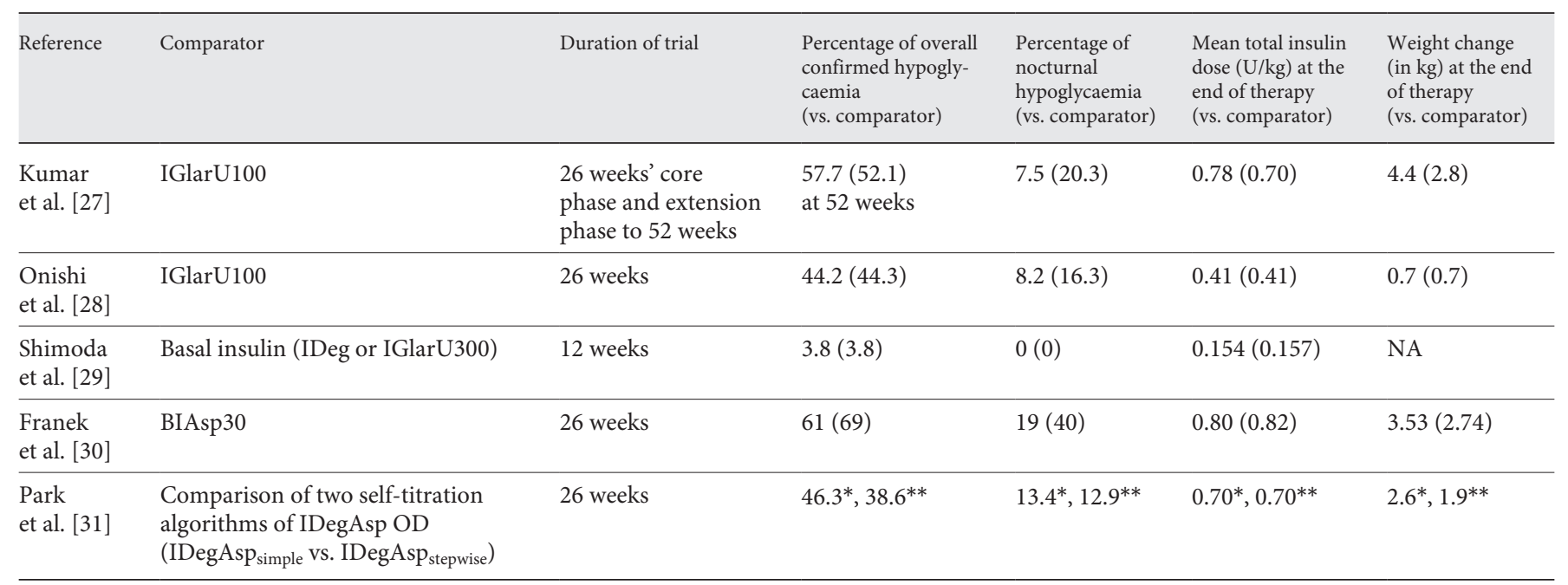

* Twice weekly titration, based on a single pre-breakfast self-monitored plasma glucose (SMPG) measurement. ${ }^{* *}$ Weekly titration, based on the lowest of three consecutive pre-breakfast SMPG measurements. NA, not reported in the text or supplementary appendix.

IDegAsp ( $n=197)$ was compared with BIAsp30 ( $n=197)$. IDegAsp showed superior fasting glucose reduction and reduced overall and nocturnal confirmed hypoglycaemia at a similar overall insulin dose [30]. In a trial testing various titration regimens of IDegAsp, simple titration regimens fared as well as a step-wise titration regimen [31]. In most trials with self-monitoring of blood glucose, people on IDegAsp had lower PPG compared to the other arm $[27,28]$.

\section{Evidence with IDegLira (Tables 4, 5)}

DUAL VIII ( $n=1,012$, mean age: 56.8 years, duration of diabetes: 10.0 years), a 104-week duration study, was designed to test the durability of IDegLira in comparison with IGlarU100. IDegLira was found to be more durable by the metric of time from randomisation to inadequate glycaemic control and treatment intensification. At 104 weeks, $37 \%$ of the people on IDegLira required treatment intensification compared to $66 \%$ of the people on IGlarU100 [32].

In DUAL I ( $n=1,663$, mean age: 55.1 years, duration of diabetes: 6.6 years), IDegLira was compared to degludec and liraglutide in a 3 -arm randomised controlled trial of 26 weeks' duration in insulin-naïve people with type 2 diabetes on metformin and pioglitazone. The mean $\mathrm{HbA} 1 \mathrm{c}$ reduction was $-1.9,-1.4$, and $-1.3 \%$ in the IDegLira, IDeg, and liraglutide arm, respectively. Significantly more people achieved target $\mathrm{HbAlc}$ of $53 \mathrm{~mol} / \mathrm{mol}(7 \%)$ on IDegLira $(81 \%)$ compared to IDeg $(65 \%, p<0.0001)$

Co-Formulations as the First Injectable in

Type 2 Diabetes or liraglutide $(60 \%, p<0.0001)$. More people in the IDegLira arm (36\%) achieved target HbAlc without hypoglycaemia and weight gain compared to IDeg $(14 \%, p<$ 0.0001) [33]. During an extension phase of the DUAL I study, at 52 weeks, significantly more people achieved target $\mathrm{HbAlc}$ of $53 \mathrm{~mol} / \mathrm{mol}$ (7\%) on IDegLira (78.2\%) compared to IDeg $(62.5 \%, p<0.0001)$ or liraglutide $(56.5 \%, p<0.0001)$ [34].

In a 52-week trial (DUAL I Japan) in Japanese people ( $n=819$, mean age: 56.9 years, duration of diabetes: 9.2 years), IDegLira was compared to both IDeg and liraglutide in a 1:1:1 randomisation. IDegLira was found to be superior to IDeg and liraglutide for reaching the primary endpoint of $\mathrm{HbA} 1 \mathrm{c}$ reduction [35].

In a 26 -week trial ( $n=420$, mean age: 56.1 years, duration of diabetes: 9.8 years), IDegLira was compared to IGlarU100 in people with type 2 diabetes on oral glucoselowering drugs including SGLT2 inhibitors. In this trial, IDegLira was non-inferior to IGlarU100 for the primary endpoint of reduction of $\mathrm{HbAlc}$ from baseline to end of trial and superior for change in HbA1c [36].

In a 26-week double-blind trial, adults with type 2 diabetes were randomised to IDegLira $(n=289)$ or placebo $(n=146)$ as add-on to pre-trial sulphonylureas \pm metformin (DUAL IV). The study showed that IDegLira was superior to placebo with regard to $\mathrm{HbAlc}$ reduction from baseline $(-14 \mathrm{mmol} / \mathrm{mol}[1.5 \%]$ vs. $-5 \mathrm{mmol}[0.5 \%], p<$ 0.001 ) and proportion of people attaining the targets (79.2 vs. $28.8 \%$, $p$ value $<0.001$ ) [37].

Dubai Diabetes Endocrinol J 2020;26:139-15 143 


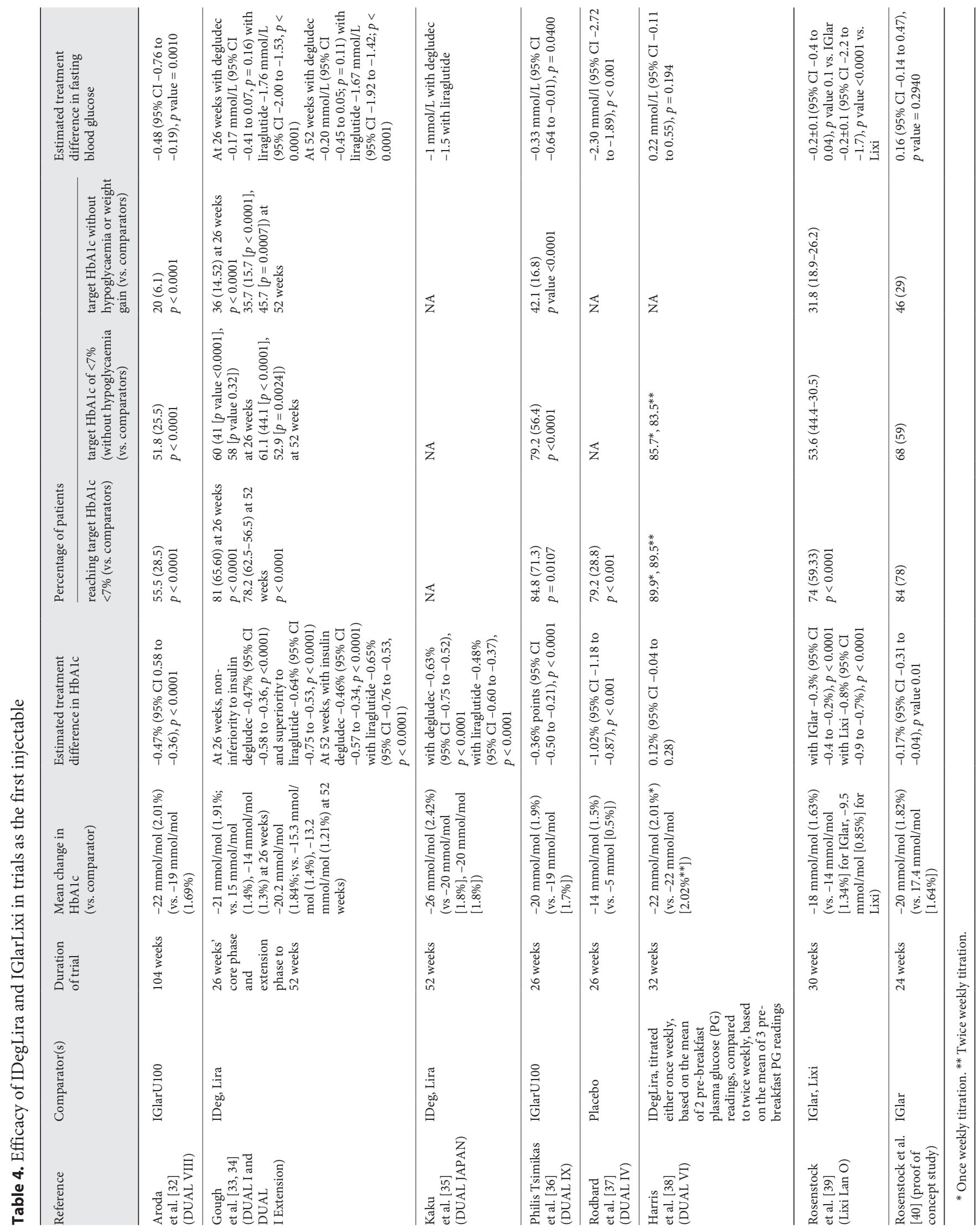


Table 5. Safety, doses, and weight changes in trials of IDegLira and IGlarLixi when used as the first injectable

\begin{tabular}{|c|c|c|c|c|c|c|}
\hline Reference & Comparator(s) & Duration of trial & $\begin{array}{l}\text { Overall confirmed } \\
\text { hypoglycaemia } \\
\text { (vs. comparators) }\end{array}$ & $\begin{array}{l}\text { Percentage of patients } \\
\text { affected by GI side effects } \\
\text { (vs. comparators) }\end{array}$ & $\begin{array}{l}\text { Mean dose of GLP } 1 \\
\text { analogue in co-formulation } \\
\text { at the end of therapy }\end{array}$ & $\begin{array}{l}\text { Weight change (in } \mathrm{kg} \text { ) } \\
\text { at the end of therapy } \\
\text { (vs. comparators) }\end{array}$ \\
\hline $\begin{array}{l}\text { Aroda et al. [32] } \\
\text { (DUAL VIII) }\end{array}$ & IGlarU100 & 104 weeks & $25.7 \%(31 \%)$ & $14(4)$ & $1.296 \mathrm{mg}$ & $1.7(3.4)$ \\
\hline $\begin{array}{l}\text { Gough et al. } \\
{[33,34] \text { (DUAL I }} \\
\text { and DUAL I Extension) }\end{array}$ & IDeg, Lira & $\begin{array}{l}26 \text { weeks' core } \\
\text { phase and } \\
\text { extension phase } \\
\text { to } 52 \text { weeks }\end{array}$ & $\begin{array}{l}32 \%(39 \%, 7 \%) \\
\text { at } 26 \text { weeks } \\
176.7 \text { episodes/100 PYE } \\
(279.1 / 100 \text { PYE,19.1 } \\
\text { episodes/100 PYE) } \\
\text { at } 52 \text { weeks }\end{array}$ & 21 (10.41) at 26 weeks & $1.4 \pm 0.5 \mathrm{mg}$ & $\begin{array}{l}-2.80 \mathrm{~kg} \text { (vs. IDeg) } \\
+2.66 \mathrm{~kg} \text { (vs. Lira) }\end{array}$ \\
\hline $\begin{array}{l}\text { Kaku et al. [35] } \\
\text { (DUAL JAPAN) }\end{array}$ & IDeg, Lira & 52 weeks & $38.5 \%(54.6 \%, 2.2 \%)$ & $18.6(10.6,31.1)$ & $1 \mathrm{mg}$ & $\begin{array}{l}-3.2 \mathrm{~kg} \text { (vs. IDeg) } \\
+2.2 \mathrm{~kg} \text { (vs. Lira) }\end{array}$ \\
\hline $\begin{array}{l}\text { Philis-Tsimikas } \\
\text { et al. [36] (DUAL IX) }\end{array}$ & IGlarU100 & 26 weeks & $12.9 \%(19.5 \%)$ & NA & $1.3 \pm 0.48 \mathrm{mg}$ & $0(2)$ \\
\hline $\begin{array}{l}\text { Rodbard et al. [37] } \\
\text { (DUAL IV) }\end{array}$ & Placebo & 26 weeks & $41.7 \%(17.1 \%)$ & $11.1(10.9)$ & $1 \mathrm{mg}$ & $0.5(-1.0)$ \\
\hline $\begin{array}{l}\text { Harris et al. [38] } \\
\text { (DUAL VI) }\end{array}$ & $\begin{array}{l}\text { IDegLira, titrated either } \\
\text { once weekly, based on the } \\
\text { mean of } 2 \text { pre-breakfast } \\
\text { plasma glucose (PG) } \\
\text { readings, compared to twice } \\
\text { weekly, based on the mean } \\
\text { of } 3 \text { pre-breakfast PG } \\
\text { readings }\end{array}$ & 32 weeks & $5.7 \% *, 16.2 \% *$ & NA & $1.476 \mathrm{mg}$ & $-1^{*},-2^{* *}$ \\
\hline $\begin{array}{l}\text { Rosenstock et al. [39] } \\
\text { (Lixi Lan O) }\end{array}$ & IGlar, Lixi & 30 weeks & $25.6 \%(23.6 \%, 6.4 \%)$ & $21.7(12.6,36.90)$ & 13.1 & $-0.3(1.1$ to -2.3$)$ \\
\hline $\begin{array}{l}\text { Rosenstock et al. [40] } \\
\text { (proof of concept study) }\end{array}$ & IGlar & 24 weeks & $21.7 \%(22.8 \%)$ & $15.5(9.3)$ & NA & $0.39(-1.16)$ \\
\hline
\end{tabular}

The DUAL VI trial ( $n=420$, BMI: 32.4, duration: 7.3 years) compared the 2 different titration regimens of IDegLira and showed that once weekly and twice weekly dose titration regimens were similar in safety and efficacy [38].

In trials where PPG was evaluated, IDegLira reduced the PPG significantly compared to the other arm $[32,33$, $36,38]$.

\section{Evidence with IGlarLixi (Tables 4, 5)}

IGlarLixi has been compared to IGlar and lixisenatide as the initial injectable in people with type 2 diabetes on metformin monotherapy or oral glucose-lowering agents. In a trial lasting 30 weeks, IGlarLixi was associated with a larger reduction in $\mathrm{HbA1c}$ and more people in the IGlarLixi arm (74\%) reaching an $\mathrm{HbA} 1 \mathrm{c}<53 \mathrm{~mol} / \mathrm{mol}(7 \%)$ in comparison to IGlar $(59 \%, p$ value $<0.0001)$ and Lixi $(33 \%, p$ value $<0.0001)$. People on IGlarLixi had less risk of weight gain and better PPG in comparison to IGlar $(-2.4 \mathrm{mmol} / \mathrm{L} \pm 0.2)$ [39]. In a proof of concept study lasting 24 weeks in people on metformin, $\mathrm{HbAlc}$ reduced from $64 \mathrm{mmol} / \mathrm{mol}(8 \%)$ at baseline to $45 \mathrm{mmol} / \mathrm{mol}$
(6.3\%) in people on IGlarLixi vs. to $48 \mathrm{mmol} / \mathrm{mol}(6.5 \%)$ in people on IGlarU100 $(p=0.01)$. IGlarLixi improved 2 -h post-meal glucose vs. IGlarU100 (-3.2 mmol/L, $p<$ 0.0001 ) and body weight [40].

\section{Clinical Considerations with the Use of Co-Formulations}

\section{Hypoglycaemia}

The trials of co-formulations defined hypoglycaemia in various ways: confirmed hypoglycaemia (plasma glucose $<3.1$ or $3.8 \mathrm{mmol} / \mathrm{L}$ ), severe hypoglycaemia (requiring assistance), and nocturnal hypoglycaemia (occurring between 00:01 and 05:59). The number of people reporting hypoglycaemia and number of hypoglycaemic episodes/patient years (100 patient years) were also reported in most studies. When the comparator was basal insulin analogue, there was no significant benefit of IDegAsp on the reduction of overall or confirmed hypoglycaemia. However, fewer episodes of nocturnal hypoglycaemia 
were seen in people on IDegAsp in comparison to those on basal insulin [27-29]. However, in a trial comparing IDegAsp to BIAsp30, people randomised to the IDegAsp arm fared better in terms of overall confirmed hypoglycaemic episodes, nocturnal hypoglycaemic episodes, and number of people experiencing hypoglycaemia [30] (Table 3).

In trials comparing IDegLira to IGlarU100, people on IDegLira had a significantly lower risk of overall hypoglycaemia and nocturnal hypoglycaemia $[32,36]$. In trials where IDegLira was compared to liraglutide, people on IDegLira experienced more episodes of hypoglycaemia than those on liraglutide $[33,35]$. In a study on LixiLan $\mathrm{O}$, the number of hypoglycaemic events was low and was similar in the IGlarLixi and IGlar groups [40] (Table 5). The lower $\mathrm{HbAlc}$ and higher overall hypoglycaemia rates in trials of IDegLira in comparison to IGlarLixi are related to lower FPG titration targets in the IDegLira studies, variable definitions of hypoglycaemia, and a higher FPG reduction of liraglutide.

\section{Weight Gain}

Obesity is one of the major risk factors for cardiovascular disease. People who gain weight during insulin therapy have an adverse cardiometabolic profile as evidenced by higher body fat, trunk fat, abnormal lipid profiles, elevated transaminases, and a worse cardiovascular profile $[41,42]$. In most trials comparing IDegAsp to basal insulin or BIAsp30, weight gain was similar in people in both arms $[28,30]$. In one trial, higher weight gain was noted with IDegAsp, associated with a higher dose of insulin and a higher risk of hypoglycaemia [27]. In trials comparing IDegLira or IGlarLixi with basal insulin, people on these drugs experienced less weight gain in comparison to those on basal insulin [32, 33, 35, 36, 39]. Liraglutide has been shown to attenuate insulin-induced weight gain [43]. In trials where a GLP-1RA was used as comparator, weight loss was more pronounced in GLP-1RA alone groups $[33,35,40]$.

\section{Drug Dosages}

In most trials of IDegAsp in comparison with basal insulins or BIAsp30, the dose of insulin was similar. In one treat-to-target trial involving multi-ethnic populations, IDegAsp doses were higher than IGlarU100. This trial used IDegAsp before breakfast and had a higher risk of overall and confirmed hypoglycaemia and weight gain than people using IGlarU100 [27]. The doses of insulin (U/kg body weight) were lower in trials involving a Japanese population [28]. Although a possible effect of ethnic variations on insulin doses cannot be excluded, one of the trials used a conservative target of FPG (4.4-7.16 mmol/L) for titrations. In a trial where some of the people used IGlarU300, the doses of IGlarU300 were $26 \%$ more than those of IDegAsp [29]. In trials where IDegLira and IGlarLixi were compared to basal insulin, the doses of insulin used were significantly lower in the co-formulation group. This effectively translated into lower weight gain and hypoglycaemia $[32,33,35,36]$. Studies have shown that one of the determinants of weight gain was the insulin dose [44]. In studies where IDegLira or IGlarLixi was compared to GLP-1RA, the effective dose of liraglutide/ lixisenatide was lesser in the former $[33,35,39]$.

\section{Cardiovascular Effects}

Co-formulations contain components that have proven cardiovascular safety. The cardiovascular safety of glargine and degludec were demonstrated in the Outcome Reduction with Initial Glargine Intervention (ORIGIN) trial and in the Trial Comparing Cardiovascular Safety of Insulin Degludec versus Insulin Glargine in $\mathrm{Pa}$ tients with Type 2 Diabetes at High Risk of Cardiovascular Events (DEVOTE), respectively $[45,46]$. In DEVOTE, $8 \%$ of all people were on GLP-1RA at baseline. In a subgroup analysis of DEVOTE, there was no difference in primary outcome by baseline cardiovascular status, insulin use, diabetes duration, or baseline HbA1c [46]. No comparison by baseline use of GLP-1RA was done. Although aspart has not been included in any cardiovascular outcome trial, the Nippon Ultra-Rapid Insulin and Diabetic Complication Evaluation (NICE) study showed a significant $43 \%$ decrease in the cumulative cardiovascular event rate for the insulin aspart group in comparison to the human regular insulin group [47].

The cardiovascular safety of lixisenatide and liraglutide were demonstrated in the Evaluation of Lixisenatide in Acute Coronary Syndrome (ELIXA) and the Liraglutide Effect and Action in Diabetes: Evaluation of Cardiovascular Outcome Results (LEADER) trials, respectively which enrolled people with diabetes and a high cardiovascular risk $[48,49]$. In a subgroup analysis of LEADER, there was no difference in the primary outcome for people stratified by baseline use of insulin [49]. The mean daily dose of liraglutide used in LEADER was $1.78 \mathrm{mg} /$ day in comparison to a mean dose of 1.0-1.48 mg in phase 3 trials of IDegLira. In a post hoc analysis of the DEVOTE trial, the use of liraglutide was associated with a significantly lower risk of major adverse cardiovascular events and death in patients with type 2 diabetes and a high cardiovascular risk using basal insulin [50]. IDegLira had fa- 
vourable effects on various cardiovascular risk factors in a post hoc analysis of various DUAL trials $[51,52]$. In trials of co-formulations, the cardiovascular events were small in number and balanced between the groups. Although none of the co-formulations are included in a cardiovascular outcome trial, the cardiovascular safety of these combinations can be reassured due to the safety of these molecules in their individual trials.

\section{Gastrointestinal Adverse Effects}

One of the major reasons for drop out of people in trials using GLP-1RA is the risk of gastrointestinal adverse effects. In trials of IDegLira, 1.1 people per 100 patient years reported gastrointestinal adverse effects, and 0.5\% dropped out due to these. In studies where liraglutide was the comparator, this was lower than in the IDegLira arm in the initial 10 weeks but stabilised later [53]. The smaller likelihood of gastrointestinal adverse effects in the coformulations involving GLP-1RA is likely due to the slow titration of GLP-1RA and lower final dose. In DUAL I, the mean dose of liraglutide in the IDegLira arm was 1.4 $\mathrm{mg}$ and in the liraglutide arm it was $1.8 \mathrm{mg}$ daily [33].

Although pancreatic enzymes like amylase and lipase were increased in people using liraglutide in LEADER (mean dose: $1.78 \mathrm{mg} /$ day) and SCALE (mean dose: $3 \mathrm{mg} /$ day), a meta-analysis involving GLP-1RA failed to show any increased risk of pancreatitis or pancreatic cancer [54-56]. In regulatory trials involving IDegLira, there was no increased risk of pancreatitis although an elevation of lipase and amylase was documented [53]. In trials involving IDegLira, the mean dose of liraglutide ranged from 1.0 to $1.48 \mathrm{mg}$. No imbalance of adverse effects between the groups related to the pancreas was seen in trials involving IDegLira or IGlarLixi. People with previous pancreatic diseases were not enrolled in trials involving coformulations of GLP-1RA.

In the LEADER trial, acute gallbladder or biliary disease occurred more often with liraglutide, with similar trends for uncomplicated gallbladder stones, complicated gallbladder stones, cholecystitis, biliary obstruction, and the need for cholecystectomy [57]. The number of cases with gall bladder disease was also increased in people in the lixisenatide arm of ELIXA [48]. The mechanism for this effect is unclear but may relate to the saturation of bile during weight loss as well as the alterations in biliary motility [57]. Gall bladder-related events are few in people in trials of IDegLira and IGlarLixi and were balanced between the arms $[26,53]$. Gastrointestinal adverse effects can limit the use of these co-formulations in people with these adverse effects.

Co-Formulations as the First Injectable in

Type 2 Diabetes

\section{Adherence and Injection Burden}

Adherence to antidiabetic therapies is associated with a reduction in $\mathrm{HbA1c}$, hypoglycaemia, hospitalisation, and acute complications [58]. In trials involving IDegAsp, the discontinuation rates werelow and fairly matched in both arms $[27,28]$. In trials where IDegLira was compared to basal insulin, the discontinuation rates were low and were similar in most trials $[32,33]$. However, the discontinuation rates were higher with GLP-1RA (liraglutide or lixisenatide) when compared to co-formulations (IDegLira and IGlarLixi) apart from one trial which involved Japanese people [35]. The continuation rates for drugs like liraglutide in real world registries are much smaller than those in randomised trials $[59,60]$. The possible reasons include adverse effects, inability to reach glycaemic or weight loss targets, and cost of therapy.

As first injectables, co-formulations offer the advantage of a smaller number of injections in comparison to GLP-1RA added to basal insulin, prandial insulin, and premixed insulin. In a multinational audit of GLP-1RA prescriptions, a lower injection frequency translated to a better adherence to medications [61]. Intensifying basal insulin is one of the areas in glycaemic management with significant clinical inertia. In people studied from the UK Clinical Practice Research Datalink database, the median time of intensification from basal insulin initiation was 4.3 years [62]. By substituting basal insulin with a co-formulation, this bridge of clinical inertia can be significantly reduced.

\section{Dosing and Flexibility Limitations}

The flexibility of co-formulations is limited by the fixed ratio of its components. In most studies of IDegAsp, the dose titrations were governed by FPG targets. A target FPG of 4.0-5.0 mmol/L or hypoglycaemia can limit the upward titration of IDegAsp. In studies where IDegAsp was used twice daily, the pre-breakfast dose of IDegAsp was titrated using the pre-dinner plasma glucose [30]. Unlike the protaminated aspart in BIAsp30, the IDeg component of IDegAsp lasts beyond $24 \mathrm{~h}$ making pre-dinner monitoring redundant for dose titrations of morning dose of IDegAsp [63]. Using the plasma PPG after the meal where IDegAsp is given or the pre-prandial plasma glucose before the subsequent meal is more appropriate. The controlled post-meal plasma glucose after the meal, where IDegAsp was given, or a target pre-meal plasma glucose before the next meal will limit the up-titration of the dose of a shortacting component (aspart). Most of the studies that used one daily IDegAsp used it before the largest meal

Dubai Diabetes Endocrinol J 2020;26:139-15 147 
of the day, although one study used it before breakfast in all people. In this study, there was an increased risk of hypoglycaemia in the $4 \mathrm{~h}$ subsequent to the dose, proving the limitation of using FPG for titrating IDegAsp [27]. This remains one of the limitations of IDegAsp when people can have hypoglycaemia due to the short-acting component (aspart) of the co-formulation with the FPG still remaining high due to inadequacy of the long-acting component (degludec). The mean doses of IDegAsp required in treat-to-target trials of initiation range from 28 to 75 units.

Dose titration of co-formulations are limited by the maximum capacity of their disposable and reusable pens and the maximum permissible doses of their GLP-1RA components (Table 1): FPG remaining uncontrolled after these ceiling doses should be managed with additional basal insulin. There is a theoretical risk of uncontrolled post-prandial hyperglycaemia in the face of normal FPG in people using IDegLira or IGlarLixi. This may require the use of short-acting insulin analogues. Further, in these combinations, a significant percentage of people may not reach the maximal dose of GLP-1RA due to limitations imposed by dose titrations of basal insulin.

\section{Cost Effectiveness}

Cost is a major cause of drug non-adherence [64]. Drugs with benefits like lesser hypoglycaemia, less weight gain, and cardiovascular protection may reduce the overall risk of hospitalisation and cardiovascular events resulting in cost savings for the health care system. A short-term cost-effectiveness model showed that IDegAsp is a cost-effective treatment compared with BIAsp30 for people with type 2 diabetes mellitus. This result was driven by significant reductions in severe hypoglycaemia and lower insulin doses observed with IDegAsp versus BIAsp30 [65]. The cost-effectiveness of IDegLira (against basal bolus regimen, the addition of liraglutide, and up-titration of basal insulin) and IGlarLixi (against premixed insulin) was also shown in populations uncontrolled on basal insulin [66-68]. In a study on an Italian population, IDegLira was found to be costeffective in comparison to IGlarLixi due to a delay in diabetes complications despite the high acquisition costs of IDegLira [69]. The cost-effectiveness of these drugs in injection-naïve people is not available. However, the generalisability of health-economic analyses in one population to various populations and payer models are questionable [70].

\section{Renal Effects}

Changes in renal function may affect the clearance of drugs leading to accumulation and adverse effects. Changes in eGFR did not affect the pharmaco-kinetic and pharmaco-dynamic characteristics of IDegAsp [71]. The eGFR cut-off of liraglutide and lixisenatide applies to their respective co-formulations. No overall differences in safety or efficacy were seen in these people with reduced renal function in the LEADER trial compared to people with normal renal function. Data for liraglutide is limited in people with end-stage renal disease [71].

Progression to macro-albuminuria was reduced in people enrolled in the GLP-1RA arm of the LEADER and ELIXA trials $[48,72]$. Since a significant number of subjects in these trials were on maximum approved doses of the drug, the effect of lesser doses of GLP-1RA used in patients on IDegLira and IGlarLixi cannot be equated.

\section{Conclusion}

Co-formulations involving insulin and insulin-GLP1RA are valuable additions to the current armamentarium of glucose-lowering agents. IDegAsp has a place as the first injectable in all people requiring insulin for initiation, intensification from basal insulin, or as a reasonable substitute to basal-bolus insulin in people with type $2 \mathrm{di}$ abetes. Since IDegAsp is more expensive than IGlarU100, physicians should weigh the relative benefits of IDegAsp in comparison to IGlarU 100 and BiAsp30 while choosing this drug. Insulin-GLP-1RA fixed drug combinations are important drugs which help more people achieve target $\mathrm{HbAlc}$ without weight gain and a low risk of hypoglycaemia. They can be used as the first injectable in all people with type 2 diabetes or as intensification for people initiated on GLP-1RA or basal insulin. These agents help simplify injectables so that better and durable glycaemic control can be achieved safely with minimal injection burden and improved adherence. The cost of these agents in comparison to basal insulin may limit their widespread use.

\section{Conflict of Interest Statement}

M.J. served on the speaker bureau for Novo Nordisk, Eli Lilly, Sanofi India, Astra Zeneca, Boehringer Ingelheim, and MSD. D.G. served on the speaker bureau for Novo Nordisk, Astra Zeneca, and MSD. T.O. served on the speaker bureau for Novo Nordisk, Eli Lilly, Sanofi India, Astra Zeneca, MSD, and Boehringer Ingelheim. 


\section{Funding Sources}

There are no funding sources to be reported.

\section{Author Contributions}

M.J.: conception of the work, searching for articles, preliminary draft, analysis, interpretation, and drafting of the article. D.G.: writing the preliminary draft, data analysis, interpretation, and final drafting of the article. T.O.: writing the preliminary draft, data analysis, interpretation, and final drafting of the article.

\section{References}

1 Yang W, Dall TM, Beronjia K, Lin J, Semilla AP, Chakrabarti R, et al.; American Diabetes Association. Economic costs of diabetes in the U.S. in 2017. Diabetes Care. 2018 May;41(5): 917-28.

2 American Diabetes Association. 9. Pharmacologic approaches to glycemic treatment: standards of medical care in diabetes - 2020 . Diabetes Care. 2020 Jan;43(Suppl 1):S98-110.

3 Buse JB, Wexler DJ, Tsapas A, Rossing P, Mingrone G, Mathieu C, et al. 2019 update to: management of hyperglycemia in type 2 diabetes, 2018: a consensus report by the American Diabetes Association (ADA) and the European Association for the Study of Diabetes (EASD). Diabetes Care. 2020 Feb;43(2):48793.

4 Lipscombe L, Booth G, Butalia S, Dasgupta K, Eurich DT, Goldenberg R, et al.; Diabetes Canada Clinical Practice Guidelines Expert Committee. Pharmacologic glycemic management of type 2 diabetes in adults. Can J Diabetes. 2018 Apr;42(Suppl 1):S88-103.

5 Aschner P; International Diabetes Federation. New IDF clinical practice recommendations for managing type 2 diabetes in primary care. Diabetes Res Clin Pract. 2017 Oct;132: 169-70.

6 Russell-Jones D, Vaag A, Schmitz O, Sethi BK, Lalic N, Antic S, et al.; Liraglutide Effect and Action in Diabetes 5 (LEAD-5) met+SU Study Group. Liraglutide vs insulin glargine and placebo in combination with metformin and sulfonylurea therapy in type 2 diabetes mellitus (LEAD-5 met+SU): a randomised controlled trial. Diabetologia. 2009 Oct; 52(10):2046-55.

7 Diamant M, Van Gaal L, Guerci B, Stranks S, Han J, Malloy J, et al. Exenatide once weekly versus insulin glargine for type 2 diabetes (DURATION-3): 3-year results of an openlabel randomised trial. Lancet Diabetes Endocrinol. 2014 Jun;2(6):464-73.

8 Giorgino F, Benroubi M, Sun JH, Zimmermann AG, Pechtner V. Efficacy and safety of once-weekly dulaglutide versus insulin glargine in patients with type 2 diabetes on metformin and glimepiride (AWARD-2). Diabetes Care. 2015 Dec;38(12):2241-9.

9 Aroda VR, Bain SC, Cariou B, Piletič M, Rose L, Axelsen M, et al. Efficacy and safety of once-weekly semaglutide versus once-daily insulin glargine as add-on to metformin (with or without sulfonylureas) in insulinnaive patients with type 2 diabetes (SUSTAIN 4): a randomised, open-label, parallel- group, multicentre, multinational, phase 3a trial. Lancet Diabetes Endocrinol. 2017 May; 5(5):355-66.

10 Kalra S, Czupryniak L, Kilov G, Lamptey R, Kumar A, Unnikrishnan AG, et al. Expert opinion: patient selection for premixed insulin formulations in diabetes care. Diabetes Ther. 2018 Dec;9(6):2185-99.

11 Mohan V, Kalra S, Kesavadev J, Singh AK, Kumar A, Unnikrishnan AG, et al. Consensus on initiation and intensification of premix insulin in type 2 diabetes management. J Assoc Physicians India. 2017 Apr;65(4):59-73.

12 Garber AJ, King AB, Del Prato S, Sreenan S, Balci MK, Muñoz-Torres M, et al.; NN12503582 (BEGIN BB T2D) Trial Investigators. Insulin degludec, an ultra-longacting basal insulin, versus insulin glargine in basal-bolus treatment with mealtime insulin aspart in type 2 diabetes (BEGIN Basal-Bolus Type 2): a phase 3, randomised, open-label, treat-totarget non-inferiority trial. Lancet. $2012 \mathrm{Apr}$; 379(9825):1498-507.

13 Bolli GB, Riddle MC, Bergenstal RM, Ziemen M, Sestakauskas K, Goyeau H, et al.; on behalf of the EDITION 3 study investigators. New insulin glargine $300 \mathrm{U} / \mathrm{ml}$ compared with glargine $100 \mathrm{U} / \mathrm{ml}$ in insulin-naïve people with type 2 diabetes on oral glucose-lowering drugs: a randomized controlled trial (EDITION 3). Diabetes Obes Metab. 2015 Apr; 17(4):386-94.

14 Giugliano D, Maiorino MI, Bellastella G, Chiodini P, Esposito K. Treatment regimens with insulin analogues and haemoglobin Alc target of $<7 \%$ in type 2 diabetes: a systematic review. Diabetes Res Clin Pract. 2011 Apr;92(1): $1-10$.

15 Buse JB, Wolffenbuttel BH, Herman WH, Hippler S, Martin SA, Jiang HH, et al. The DURAbility of Basal versus Lispro mix 75/25 insulin Efficacy (DURABLE) trial: comparing the durability of lispro mix 75/25 and glargine. Diabetes Care. 2011 Feb;34(2):249-55.

16 Riddle M, Umpierrez G, DiGenio A, Zhou R, Rosenstock J. Contributions of basal and postprandial hyperglycemia over a wide range of $\mathrm{AlC}$ levels before and after treatment intensification in type 2 diabetes. Diabetes Care. 2011 Dec;34(12):2508-14.

17 Umpierrez GE, Skolnik N, Dex T, Traylor L, Chao J, Shaefer C. When basal insulin is not enough: A dose-response relationship between insulin glargine 100 units/mL and glycaemic control. Diabetes Obes Metab. 2019 Jun;21(6):1305-10.
18 Bajaj S. RSSDI clinical practice recommendations for the management of type 2 diabetes mellitus 2017. Int J Diabetes Dev Ctries. 2018 Mar;38(Suppl 1):1-115.

19 Silver B, Ramaiya K, Andrew SB, Fredrick O, Bajaj S, Kalra S, et al. EADSG Guidelines: insulin therapy in diabetes. Diabetes Ther. 2018 Apr;9(2):449-92.

20 Kalra S, Latif ZA, Comlekci A, Galvez GG, Malik R, Pathan MF, et al. Pragmatic use of insulin degludec/insulin aspart co-formulation: a multinational consensus statement. Indian J Endocrinol Metab. 2016 Jul-Aug;20(4): 542-5.

21 Kalra S, Gupta Y. Injectable coformulations in diabetology. Diabetes Ther. 2015 Jun;6(2): 101-11.

22 Food and Drug Administration. Insulin degludec/liraglutide (IDegLira) treatment to improve glycemic control in adults with type 2 diabetes mellitus briefing document endocrinologic and metabolic drug advisory committee [Internet]. New Hampshire Ave: Food and Drug Administration; May 24, 2016 [cited Jan 15, 2020]. Available from: https://www. fda.gov/media/97814/download.

23 Inman TR, Plyushko E, Austin NP, Johnson JL. The role of basal insulin and GLP-1 receptor agonist combination products in the management of type 2 diabetes. Ther Adv Endocrinol Metab. 2018 May;9(5):151-5.

24 Perreault L, Rodbard H, Valentine V, Johnson E. Optimizing fixed-ratio combination therapy in type 2 diabetes. Adv Ther. 2019 Feb; 36(2):265-77.

25 Hinnen D, Strong J. iGlarLixi: A new oncedaily fixed-ratio combination of basal insulin glargine and lixisenatide for the management of type 2 diabetes. Diabetes Spectr. 2018 May; 31(2):145-54.

26 Food and Drug Administration. Lixisenatide and iGlarLixi (insulin glargine/lixisenatide fixed-ratio combination) for the treatment of type 2 diabetes mellitus. Briefing document for the Endocrinologic and Metabolic Drugs Advisory Committee [Internet]. New Hampshire Ave: Food and Drug Administration; May 25, 2016 [cited Nov 16, 2019]. Available from: https://www.fda.gov/media/97767/download.

27 Kumar A, Franek E, Wise J, Niemeyer M, Mersebach H, Simó R. Efficacy and safety of once-daily insulin degludec/insulin aspart versus insulin glargine (U100) for 52 weeks in insulin-naïve people with type 2 diabetes: A randomized controlled trial. PLoS One. 2016; 11(10):e0163350. 
28 Onishi Y, Ono Y, Rabøl R, Endahl L, Nakamura S. Superior glycaemic control with oncedaily insulin degludec/insulin aspart versus insulin glargine in Japanese adults with type 2 diabetes inadequately controlled with oral drugs: a randomized, controlled phase 3 trial. Diabetes Obes Metab. 2013 Sep;15(9):826-32.

29 Shimoda S, Sakamoto W, Hokamura A, Matsuo Y, Sekigami T, Ichimori S, et al. Comparison of the efficacy and safety of once-daily insulin degludec/insulin aspart (IDegAsp) and long-acting second-generation basal insulin (insulin degludec and insulin glargine 300 units $/ \mathrm{mL}$ ) in insulin-naïve Japanese adults with type 2 diabetes: a pilot, randomized, controlled study. Endocr J. 2019 Aug; 66(8):745-52.

30 Franek E, Haluzík M, Canecki Varžić S, Sargin $M$, Macura S, Zacho J, et al. Twice-daily insulin degludec/insulin aspart provides superior fasting plasma glucose control and a reduced rate of hypoglycaemia compared with biphasic insulin aspart 30 in insulin-naïve adults with Type 2 diabetes. Diabet Med. 2016 Apr;33(4):497-505.

31 Park SW, Bebakar WM, Hernandez PG, Macura S, Hersløv ML, de la Rosa R. Insulin degludec/insulin aspart once daily in Type 2 diabetes: a comparison of simple or stepwise titration algorithms (BOOST ${ }^{\circledR}$ : SIMPLE USE). Diabet Med. 2017 Feb;34(2):174-9.

32 Aroda VR, González-Galvez G, Grøn R, Halladin N, Haluzík M, Jermendy G, et al. Durability of insulin degludec plus liraglutide versus insulin glargine U100 as initial injectable therapy in type 2 diabetes (DUAL VIII): a multicentre, open-label, phase $3 \mathrm{~b}$, randomised controlled trial. Lancet Diabetes Endocrinol. 2019 Aug;7(8):596-605.

33 Gough SC, Bode B, Woo V, Rodbard HW, Linjawi S, Poulsen P, et al.; NN9068-3697 (DUAL-I) trial investigators. Efficacy and safety of a fixed-ratio combination of insulin degludec and liraglutide (IDegLira) compared with its components given alone: results of a phase 3 , open-label, randomised, 26week, treat-to-target trial in insulin-naive patients with type 2 diabetes. Lancet Diabetes Endocrinol. 2014 Nov;2(11):885-93.

34 Gough SC, Bode BW, Woo VC, Rodbard HW, Linjawi S, Zacho M, et al. One-year efficacy and safety of a fixed combination of insulin degludec and liraglutide in patients with type 2 diabetes: results of a 26 -week extension to a 26-week main trial. Diabetes Obes Metab. 2015 Oct;17(10):965-73.

35 Kaku K, Araki E, Tanizawa Y, Ross Agner B, Nishida T, Ranthe M, et al. Superior efficacy with a fixed-ratio combination of insulin degludec and liraglutide (IDegLira) compared with insulin degludec and liraglutide in insulinnaïve Japanese patients with type 2 diabetes in a phase 3 , open-label, randomized trial. Diabetes Obes Metab. 2019 Dec;21(12):2674-83.

36 Philis-Tsimikas A, Billings LK, Busch R, Portillo CM, Sahay R, Halladin N, et al. Superior efficacy of insulin degludec/liraglutide versus insulin glargine U100 as add-on to sodiumglucose co-transporter-2 inhibitor therapy: A randomized clinical trial in people with uncontrolled type 2 diabetes. Diabetes Obes Metab. 2019 Jun;21(6):1399-408.

37 Rodbard HW, Bode BW, Harris SB, Rose L, Lehmann L, Jarlov H, et al.; Dual Action of Liraglutide and insulin degludec (DUAL) IV trial investigators. Safety and efficacy of insulin degludec/liraglutide (IDegLira) added to sulphonylurea alone or to sulphonylurea and metformin in insulin-naïve people with Type 2 diabetes: the DUAL IV trial. Diabet Med. 2017 Feb;34(2):189-96.

38 Harris SB, Kocsis G, Prager R, Ridge T, Chandarana K, Halladin N, et al. Safety and efficacy of IDegLira titrated once weekly versus twice weekly in patients with type 2 diabetes uncontrolled on oral antidiabetic drugs: DUAL VI randomized clinical trial. Diabetes Obes Metab. 2017 Jun;19(6):858-65.

39 Rosenstock J, Aronson R, Grunberger G, Hanefeld M, Piatti P, Serusclat P, et al.; LixiLan-O Trial Investigators. Benefits of LixiLan, a titratable fixed-ratio combination of insulin glargine plus lixisenatide, versus insulin glargine and lixisenatide monocomponents in type 2 diabetes inadequately controlled on oral agents: the LixiLan-O randomized trial. Diabetes Care. 2016 Nov;39(11):2026-35.

40 Rosenstock J, Diamant M, Aroda VR, Silvestre L, Souhami E, Zhou T, et al.; LixiLan PoC Study Group. Efficacy and safety of LixiLan, a titratable fixed-ratio combination of lixisenatide and insulin glargine, versus insulin glargine in type 2 diabetes inadequately controlled on metformin monotherapy: the LixiLan proof-of-concept randomized trial. Diabetes Care. 2016 Sep;39(9):1579-86.

41 Jansen HJ, Vervoort G, van der Graaf M, Tack CJ. Pronounced weight gain in insulin-treated patients with type 2 diabetes mellitus is associated with an unfavourable cardiometabolic risk profile. Neth J Med. 2010 Nov; 68(11):359-66.

42 Purnell JQ, Zinman B, Brunzell JD, Nathan DM, Lachin JM, Zinman B, et al.; DCCT/ EDIC Research Group. The effect of excess weight gain with intensive diabetes mellitus treatment on cardiovascular disease risk factors and atherosclerosis in type 1 diabetes mellitus: results from the Diabetes Control and Complications Trial/Epidemiology of Diabetes Interventions and Complications Study (DCCT/EDIC) study. Circulation. 2013 Jan;127(2):180-7.

43 de Wit HM, Vervoort GM, Jansen HJ, de Grauw WJ, de Galan BE, Tack CJ. Liraglutide reverses pronounced insulin-associated weight gain, improves glycaemic control and decreases insulin dose in patients with type 2 diabetes: a 26 week, randomised clinical trial (ELEGANT). Diabetologia. 2014 Sep;57(9): 1812-9.

44 Balkau B, Home PD, Vincent M, Marre M, Freemantle N. Factors associated with weight gain in people with type 2 diabetes starting on insulin. Diabetes Care. 2014 Aug;37(8): 2108-13.

45 Gerstein HC, Bosch J, Dagenais GR, Díaz R, Jung H, Maggioni AP, et al.; ORIGIN Trial Investigators. Basal insulin and cardiovascular and other outcomes in dysglycemia. N Engl J Med. 2012 Jul;367(4):319-28.

46 Marso SP, McGuire DK, Zinman B, Poulter NR, Emerson SS, Pieber TR, et al.; DEVOTE Study Group. Efficacy and safety of degludec versus glargine in type 2 diabetes. $\mathrm{N}$ Engl J Med. 2017 Aug;377(8):723-32.

47 Pollock RF, Valentine WJ, Pilgaard T, Nishimura H. The cost effectiveness of rapidacting insulin aspart compared with human insulin in type 2 diabetes patients: an analysis from the Japanese third-party payer perspective. J Med Econ. 2011;14(1):36-46.

48 Pfeffer MA, Claggett B, Diaz R, Dickstein K, Gerstein HC, Køber LV, et al.; ELIXA Investigators. Lixisenatide in people with type 2 diabetes and acute coronary syndrome. $\mathrm{N}$ Engl J Med. 2015 Dec;373(23):2247-57.

49 Marso SP, Daniels GH, Brown-Frandsen K, Kristensen P, Mann JF, Nauck MA, et al.; LEADER Steering Committee; LEADER Trial Investigators. Liraglutide and cardiovascular outcomes in type 2 diabetes. $\mathrm{N}$ Engl J Med. 2016 Jul;375(4):311-22.

50 Brown-Frandsen K, Emerson SS, McGuire DK, Pieber TR, Poulter NR, Pratley RE, et al.; DEVOTE Study Group. Lower rates of cardiovascular events and mortality associated with liraglutide use in patients treated with basal insulin: a DEVOTE subanalysis (DEVOTE 10). Diabetes Obes Metab. 2019 Jun; 21(6):1437-44.

51 Vilsbøll T, Blevins TC, Jodar E, Poulter N, Tentolouris N, Ross Agner BF, et al. Fixedratio combination of insulin degludec and liraglutide (IDegLira) improves cardiovascular risk markers in patients with type 2 diabetes uncontrolled on basal insulin. Diabetes Obes Metab. 2019 Jun;21(6):1506-12.

52 Billings LK, Doshi A, Gouet D, Oviedo A, Rodbard HW, Tentolouris N, et al. Efficacy and safety of IDegLira versus basal-bolus insulin therapy in patients with type 2 diabetes uncontrolled on metformin and basal insulin: the dual VII randomized clinical trial. Diabetes Care. 2018 May;41(5):1009-16.

53 Food and Drug Administration. Summary of product characteristics Xultophy. [Internet]. New Hampshire Ave: Food and Drug Administration [cited Nov 14, 2019]. Available from: https://www.accessdata.fda.gov/drugsatfda docs/label/2016/208583s000lbl.pdf.

54 Steinberg WM, Rosenstock J, Wadden TA, Donsmark M, Jensen CB, DeVries JH. Impact of liraglutide on amylase, lipase, and acute pancreatitis in participants with overweight/ obesity and normoglycemia, prediabetes, or type 2 diabetes: secondary analyses of pooled data from the SCALE clinical development program [published correction appears in $\mathrm{Di}$ abetes Care. 2018;41:1538]. Diabetes Care. 2017 Jul;40(7):839-48 
55 Pinto LC, Falcetta MR, Rados DV, Leitão CB, Gross JL. Glucagon-like peptide-1 receptor agonists and pancreatic cancer: a meta-analysis with trial sequential analysis. Sci Rep. 2019 Feb;9(1):2375.

56 Saisho Y. Incretin-based therapy and pancreatitis: accumulating evidence and unresolved questions. Ann Transl Med. 2018 Apr;6(7): 131-131.

57 Nauck MA, Muus Ghorbani ML, Kreiner E, Saevereid HA, Buse JB; LEADER Publication Committee on behalf of the LEADER Trial Investigators. Effects of liraglutide compared with placebo on events of acute gallbladder or biliary disease in patients with type 2 diabetes at high risk for cardiovascular events in the LEADER randomized trial. Diabetes Care. 2019;42:1912-20.

58 Giorgino F, Penfornis A, Pechtner V, Gentilella R, Corcos A. Adherence to antihyperglycemic medications and glucagon-like peptide 1-receptor agonists in type 2 diabetes: clinical consequences and strategies for improvement. Patient Prefer Adherence. 2018 May;12:707-19.

59 Melzer-Cohen C, Chodick G, Husemoen LL, Rhee N, Shalev V, Karasik A. A retrospective database study of liraglutide persistence associated with glycemic and body weight control in patients with type 2 diabetes. Diabetes Ther. 2019 Apr;10(2):683-96.

60 Ostawal A, Mocevic E, Kragh N, Xu W. Clinical effectiveness of liraglutide in type 2 diabetes treatment in the real-world setting: a sys- tematic literature review. Diabetes Ther. 2016 Sep;7(3):411-38.

61 Divino V, DeKoven M, Khan FA, Boye KS Sapin H, Norrbacka K. GLP-1 RA treatment patterns among type 2 diabetes patients in five European countries. Diabetes Ther. $2017 \mathrm{Feb}$; 8(1):115-28.

62 Khunti K, Nikolajsen A, Thorsted BL, Andersen M, Davies MJ, Paul SK. Clinical inertia with regard to intensifying therapy in people with type 2 diabetes treated with basal insulin. Diabetes Obes Metab. 2016 Apr;18(4):401-9.

63 Liebl A, Prusty V, Valensi P, Kawamori R, Christiansen JS, Palmer AJ, et al. Ten years of experience with biphasic insulin aspart 30: from drug development to the latest clinical findings. Drugs. 2012 Jul;72(11):1495-520.

64 Kang H, Lobo JM, Kim S, Sohn MW. Costrelated medication non-adherence among U.S. adults with diabetes. Diabetes Res Clin Pract. 2018 Sep;143:24-33.

65 Evans M, Gundgaard J, Hansen BB. Cost-effectiveness of insulin degludec/insulin aspart versus biphasic insulin aspart in patients with type 2 diabetes from a Danish health-care perspective. Diabetes Ther. 2016 Dec;7(4):809-23.

66 Davies MJ, Glah D, Chubb B, Konidaris G, McEwan P. Cost effectiveness of IDegLira vs. alternative basal insulin intensification therapies in patients with type 2 diabetes mellitus uncontrolled on basal insulin in a UK setting. Pharmacoeconomics. 2016 Sep;34(9):953-66.

67 Dempsey M, Mocarski M, Langer J, Hunt B. Long-term cost-effectiveness analysis shows that IDegLira is associated with improved outcomes and lower costs compared with insulin glargine U100 plus insulin aspart in the US. J Med Econ. 2018 Nov;21(11):1110-8.

68 Park HY, An S, Park S, Kim DH, Kim HO, Kwon JM, et al. Cost effectiveness of insulin glargine/lixisenatide for patients with type 2 diabetes inadequately controlled on basal insulin in South Korea. Yakhak Hoeji. 2019; 63(1):1-14.

69 Pöhlmann J, Montagnoli R, Lastoria G, Parekh W, Markert M, Hunt B. Value for money in the treatment of patients with type 2 diabetes mellitus: assessing the long-term cost-effectiveness of IDegLira versus iGlarLixi in Italy. Clinicoecon Outcomes Res. 2019 Oct;11:605-14.

70 Urdahl H, Manca A, Sculpher MJ. Assessing generalisability in model-based economic evaluation studies: a structured review in osteoporosis. Pharmacoeconomics. 2006; 24(12):1181-97.

71 European Medicine Agency. Ryzodeg Summary of product characteristics [Internet]. Amsterdam: European Medicine Agency [cited Nov 15, 2019]. Available from https:// www.ema.europa.eu/en/medicines/human/ EPAR/Ryzodeg.

72 Mann JF, Ørsted DD, Brown-Frandsen K, Marso SP, Poulter NR, Rasmussen S, et al.; LEADER Steering Committee and Investigators. Liraglutide and renal outcomes in type 2 diabetes. N Engl J Med. 2017 Aug;377(9):839_ 48. 